\title{
Epidemiological profile of patients admitted with closed fractures of shaft of tibia in a tertiary government hospital
}

\author{
Uppara R.M. ${ }^{1 *}$, Jonna N. ${ }^{2}$ \\ DOI: https://doi.org/10.17511/ijphr.2015.i1.04
}

1* Uppara R.M., Assistant Professor, Department of Ortho, Rajiv Gandhi Institute of Medical Sciences, Kadapa, Andhra Pradesh, India.

2 Jonna N, Associate Professor, Department of Ortho, Rajiv Gandhi Institute of Medical Sciences, Kadapa, Andhra Pradesh, India.

Introduction: In the recent era of trauma, about one million people get seriously injured annually. Majority of them suffer from lower limb injuries. Due to lack of trauma registry in India, prediction models are not much effective. The aim of our study was to derive basic epidemiological parameters for lower limb injuries which can be used to develop better prediction models to reduce morbidities and mortalities. Materials and Methods: This study consists of 34 cases of fracture both bones of leg, tibia treated by internal fixation with interlocking tibia from August 2009 to July 2011, and followed upto November 2011. Results: The average age of cases in this study was 36.18 years. Fracture was more common in age groups between 20 to 39 years. There were 28 male patients and 6 female patients, showing male preponderance. Conclusion: This study helped us in identifying certain characteristics that may be useful for planning preventive strategies in an attempt to reduce the number of accidents pertaining to lower limbs and redirect public investment in health. We recommend further detailed study in this area to explore more interesting facts which can be made use to develop new preventive measures.

Keywords: Fractures, Bone, Epidemiology, Tibial Fractures

Corresponding Author

Uppara R.M., Assistant Professor, Department of Ortho, Rajiv Gandhi Institute of Medical Sciences, Kadapa, Andhra Pradesh, India.
How to Cite this Article

Uppara RM, Jonna N. Epidemiological profile of patients admitted with closed fractures of shaft of tibia in a tertiary government hospital. Public Health Rev Int J Public Health Res. 2015;2(1):21-24.

Available From

https://publichealth.medresearch.in/index.php/ijphr/ article/view/11
To Browse

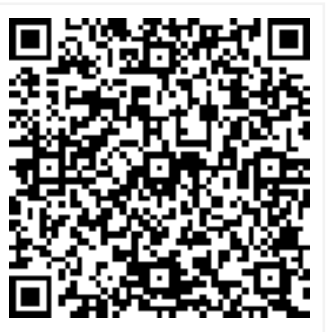

Manuscript Received 2015-03-11

Conflict of Interest No
Review Round 1 2015-03-15

Funding $\mathrm{Nil}$

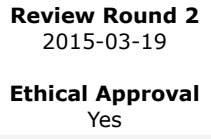

Review Round 3

Accepted 2015-03-30

Plagiarism X-checker $9 \%$

Note

(c) 2015 by Uppara R.M., Jonna N and Published by Siddharth Health Research and Social Welfare Society. This is an Open Access article licensed under a Creative Commons Attribution 4.0 International License https://creativecommons.org/licenses/by/4.0/ unported [CC BY 4.0]. 


\section{Introduction}

Tibia is the most commonly fractured long bone and the exposed anatomical location makes it vulnerable to direct blow and high-energy trauma as a result of motor vehicle accident [1]. Tibia has precarious blood supply with inadequate muscular envelope. Tibial fractures may be associated with compartment syndrome, vascular or neural injury [2]. The presence of hinge joints at the knee and the ankle, allows no adjustment for rotatory deformity after fracture.

Because of high incidence of complications, management is often difficult. Trauma accounts for about 12 percent of all causes of death worldwide. Being a significant cause for the lower limb amputations in population less than 50 years; it affects the individual and the society. Getting back into life after amputation comes with many problems. Due to failure to comply with new conditions these people may suffer from psychosocial difficulties like depression, sense of hopelessness, low self esteem, boredom, anxiety, frustration, fear of family future, which sometimes leads them to commit suicide [3].

Trauma epidemiology is essential to describe the morbidity, disability and dependency as well as defining the most important target for prevention regarding the severity of injury. The prevention of lower limb injuries is more important for developing nations like India for its economy. It has been previously shown that lower limb injuries constitute the majority in trauma and road traffic accidents [4].

\section{Materials and Methods}

The present study was a prospective study carried out in SVRRGGH, Tirupati, to know the Epidemiological Profile of Patients Admitted with Closed Fractures of Shaft of Tibia in a Tertiary Government hospital. Approval was obtained from institutional ethical committee. 34 cases of fracture both bones of leg, tibia treated by internal fixation with interlocking tibia, were recruited for the study by convenient sampling, after obtaining free, written, voluntary informed consent.

Data Analysis: Data was analyzed by using SPSS 20.0. Frequency and percentage and Chi-square test was used. Pvalue $<0.05$ was considered as significant.

\section{Results}

Results are presented in table no 1 to table no 5 . Table 1 presents descriptive data of age of the participants. Table 2 presents age group and gender of the participants. Table 3 presents age group of participants and side affected. Table 4 presents gender of participants and mechanism of injury. Table 5 presents chi-square test results.

Table No: 1 Descriptive data of age of the participants

\begin{tabular}{|l|l|}
\hline Mean & 36.18 \\
\hline Std. Error of Mean & 1.776 \\
\hline Median & 35.00 \\
\hline Mode & $25 a$ \\
\hline Std. Deviation & 10.359 \\
\hline Variance & 107.301 \\
\hline Range & 43 \\
\hline Minimum & 22 \\
\hline Maximum & 65 \\
\hline Sum & 1230 \\
\hline
\end{tabular}

Mean age of the participants is 36.18 . The range of values is 22 minimum and 65 maximum.

Table 2: Age group and sex

\begin{tabular}{|c|c|c|c|c|}
\hline \multicolumn{2}{|r|}{ Age group } & \multicolumn{2}{|c|}{ Sex } & \multirow[t]{2}{*}{ Total } \\
\hline & & $\mathrm{F}$ & M & \\
\hline \multirow[t]{2}{*}{$20-40$} & Count & 3 & 24 & 27 \\
\hline & $\%$ within age_1 & $11.1 \%$ & $88.9 \%$ & $100.0 \%$ \\
\hline \multirow[t]{2}{*}{$40-60$} & Count & 2 & 4 & 6 \\
\hline & $\%$ within age_1 & $33.3 \%$ & $66.7 \%$ & $100.0 \%$ \\
\hline \multirow[t]{2}{*}{$>60$} & Count & 1 & 0 & 1 \\
\hline & $\%$ within age_1 & $100.0 \%$ & $.0 \%$ & $100.0 \%$ \\
\hline \multicolumn{2}{|l|}{ Count } & 6 & 28 & 34 \\
\hline \multicolumn{2}{|c|}{$\%$ within age_1 } & $17.6 \%$ & $82.4 \%$ & $100.0 \%$ \\
\hline
\end{tabular}

Age and gender wise count and percentage. (Data expressed are in frequency and percentage)

Table 3: Age group and side affected

\begin{tabular}{|l|l|l|l|l|}
\hline \multicolumn{2}{|c|}{ Age group } & \multicolumn{2}{c|}{ Side affected } & \multirow{2}{*}{ Total } \\
\cline { 3 - 4 } & Left & Right & \\
\hline \multirow{2}{*}{$20-40$} & Count & 14 & 13 & 27 \\
\cline { 2 - 4 } & $\%$ within age_1 & $51.9 \%$ & $48.1 \%$ & $100.0 \%$ \\
\hline $40-60$ & Count & 1 & 5 & 6 \\
\cline { 2 - 5 } & $\%$ within age_1 & $16.7 \%$ & $83.3 \%$ & $100.0 \%$ \\
\hline \multirow{2}{*}{ Cou } & Count & 0 & 1 & 1 \\
\cline { 2 - 5 } & $\%$ within age_1 & $.0 \%$ & $100.0 \%$ & $100.0 \%$ \\
\hline Count & & 6 & 15 & 19 \\
\hline \multirow{2}{*}{$\%$ within age_1 } & $17.6 \%$ & $44.1 \%$ & $55.9 \%$ \\
\hline
\end{tabular}

Side effected count in different age groups. 
Data presentedin frequency and percentage

Table 4: Gender and mechanism of injury

\begin{tabular}{|l|l|l|l|l|}
\hline \multicolumn{2}{|c|}{ Sex } & \multicolumn{2}{|c|}{ Mechofinjury } & \multirow{2}{*}{ Total } \\
\cline { 2 - 4 } \multicolumn{2}{|c|}{} & Fall & RTA & \\
\hline F & Count & 0 & 6 & 6 \\
\cline { 2 - 5 } & $\%$ within SEX & $.0 \%$ & $100.0 \%$ & $100.0 \%$ \\
\hline M & Count & 2 & 26 & 28 \\
\hline
\end{tabular}

\begin{tabular}{|c|c|c|c|}
\hline$\%$ within SEX & $7.1 \%$ & $92.9 \%$ & $100.0 \%$ \\
\hline Count & 2 & 32 & 34 \\
\hline$\%$ within SEX & $5.9 \%$ & $94.1 \%$ & $100.0 \%$ \\
\hline
\end{tabular}

Mechanism of injury in male and female participants. RTA accounts maximum mechanism of injury in males and females.( data presented in frequency and percentage)

Table 5: Chisquare test results

\begin{tabular}{|l|l|l|l|l|l|}
\hline \multicolumn{7}{|l|}{ Chi-Square Tests } \\
\hline & Value & df & Asymp. Sig. (2-sided) & Exact Sig. (2-sided) & Exact Sig. (1-sided) \\
\hline Pearson Chi-Square & $.455 a$ & 1 & 500 & & \\
\hline Continuity Correctionb & .000 & 1 & 1.000 & & \\
\hline Likelihood Ratio & .803 & 1 & .370 & & 1.000 \\
\hline Fisher's Exact Test & & & & & .674 \\
\hline N of Valid Casesb & 34 & & & & \\
\hline a. 2 cells (50.0\%) have expected count less than 5. The minimum expected count is .35. & \\
\hline \\
b. Computed only for a 2x2 table
\end{tabular}

Results of test of significance by chi-square test. Results of fisher's exact test and correlation.

\section{Discussion}

The average age of cases in this study was 36.18 years. Fracture was more common in age groups between 20 to 39 years. Keating et al [5] study the average age group was 37. Singer et al [6] study the average age group was 36. Whittle et al [7] study the average age group was 34. Court Brown et al [8] study the average age group was 39.1. Bone and Johnson et al [9] study the average age group was 31 .

The present study agrees with earlier studies as we also observed the conditions in the same age group. There were 28 male patients and 6 female patients, showing male preponderance. Keating et al [5] study the male and female ratio was $6: 1$. Singer et al [6] and Whittle et al [7] study the male and female ratio was $3: 1$.

Court Brown et al [8] study the male and female ratio was $4: 1$. Bone and Johnson et al [9] study the male and female ratio was 4.5:1. We agree with earlier studies as we have also observed the conditions in 5:1 ratio of males and females As is evident from the chart in the chapter of observations that a large majority of patients sustained their fractures due to Road Traffic Accidents. This fact gets weightage from the reports of other studies given below.
These RTAs are common in the younger age group and involve high energy trauma. Also due to the increasing, vehicular traffic with time RTAs are becoming more prevalent. We agrees with earlier results as in our study there is 5 polytrauma cases out 32 , indicating tibia is more vulnerable to injury.

\section{Conclusion}

This study helped us in identifying certain characteristics that may be useful for planning preventive strategies in an attempt to reduce the number of accidents pertaining to lower limbs and redirect public investment in health. We recommend further detailed study in this area to explore more interesting facts which can be made use to develop new preventive measures.

\section{Limitations}

Major limitation of our study was small sample size and short study period.

\section{Reference}

\section{1. [Article] [Crossref]}

02. Michael Frink, Frank Hildebrand, Christian Krettek, Jurgen Brand, Stefan Hankemeier. Compartment Syndrome of the Lower Leg and Foot. Clin Orthop Relat Res. 2010 Apr;468(4) 940-950.

[Crossref] 
03. Goel SA, Bhavsar NM, Makwana H, Lil NA, Patel PR. Epidemiology and patterns of lower limb injuries at a tertiary care hospital in Ahmedabad. International Journal of Medical Research and Review. 06/2015;3;490.

[Crossref]

04. Miki N, Martimbianco AL, Hira LT, Lahoz GL, Fernandes HJ, Dos Reis FB. Profile of trauma victims of motorcycle accidents treated at hospital Sao Paulo. Acta Ortop Bras. 2014;22(4)219-22.

[Crossref]

05. Keating JF, O'Brien BJ, Blachut PA, et al. Locking intramedullary nailing with and without reaming for open fractures of the tibial shaft. J Bone Joint Surg Am. 1997 Mar;79(3)334-41.

[Crossref]

06. Singer RW, Kellam JF. Open tibial diaphyseal fractures- results of undreamed locked intramedullary nailing. Clin Orthop. $315 ; 114,1995$.

[Crossref]
07. Whittle AP, Russell T A, Taylor JC, Lavelle DG. Treatment of open fractures of the tibial shaft with the use of interlocking nailing without reaming. J Bone and Joint Surg. 74-A;11621171 ;Sept-1992.

[Crossref]

08. Browner BD, Wiss DA. GK locking nail for the femur- The science and practice of intramedullary nailing. Philadelphia, Lee and Febyer. 1987'.

[Crossref]

09. Dinesh Choudary. A Prospective Comparative Study of Reamed vs Unreamed Nailing in Fractures Shaft of Tibia. Malays Orthop J. 2012 Nov;6(3)21-26.

[Crossref] 